$$
\therefore \quad \text { CONF-9605162--4 }
$$

\title{
IDENTIFICATION AND SUMMARY
}

CHARACTERIZATION OF MATERIALS

POTENTIALLY REQUIRING

VITRIFICATION: BACKGROUND

INFORMATION

\section{Allen G. Croff . \\ Oak Ridge National Laboratory}

The submitted manuscript has boen

authored by a contract of the U.S.

Government under contract No. DE-ACOS-

D8OR22404. Acoordingly, the U.S.

Government retains a nonexclusive,

royalty-free license to publlat or

reproduce the publlinad form of this

contribution, or allow others to do so for

U.S. Government purpose.

\section{May 13, 1996}

\author{
Prepared by the \\ Oak Ridge National Laboratory \\ Oak Ridge, Tennessee 37831-6285 \\ managed by \\ LOCKHEED MARTIN ENERGY RESEARCH CORP. \\ for the \\ U.S. DEPARTMENT OF ENERGY \\ under contract DE-AC05-96OR22464
}


PREFACE

What follows constitutes background information for the Workshop in general and the presentation entitled Identification and Summary Characterization of Materials Potentially Requiring Vitrification that was given during the first morning of the workshop. Summary characteristics of 9 categories of U.S. materials having some potential (interpreted liberally) to be vitrified are given in Table 1. This is followed by 1-2 page elaborations for each of the 9 categories. References to even more detailed information are included. 
TABLE 1. SUMMARY OF U.S. MATERIALS HAVING SOME POTENTIAL TO BE VITRIFIED

\begin{tabular}{|c|c|c|c|c|c|}
\hline Material Type & $\begin{array}{l}\text { Volume, } \mathrm{m}^{3} \\
\text { or } \mathrm{m}^{3 / y} \text { ra }\end{array}$ & $\begin{array}{c}\text { Radioactivity } \\
\text { Density, Ci/m }\end{array}$ & $\begin{array}{c}\text { Power } \\
\text { Density, } \mathrm{W} / \mathrm{m}^{3}\end{array}$ & Material Description & $\begin{array}{l}\text { Vitrification } \\
\text { Possibilities }\end{array}$ \\
\hline 1. Spent civilian nuclear fuel & 12000 & $10,000,000$ & 50000 & Light-water reactor spent fuel & $\begin{array}{l}\text { Unlikely unless required by } \\
\text { repository }\end{array}$ \\
\hline 2. DOE spent fuel & 1200 & $\begin{array}{l}\text { Not quantifiable; } \\
\text { Moderate-to-high }\end{array}$ & $\begin{array}{l}\text { Not quantifiable; } \\
\text { Moderate-to-high }\end{array}$ & Variety of spent fuels & $\begin{array}{l}\text { Likely for Al-clad fuels, } \\
\text { possible for others }\end{array}$ \\
\hline 3. DOE "tank" wastes & 375000 & $1,000-10,000$ & $5-50$ & $\begin{array}{l}\text { Alkaline liquid, saltcake, sludge; } \\
\text { calcine }\end{array}$ & $\begin{array}{l}\text { Highly likely for essentially } \\
\text { all retrieved tank waste }\end{array}$ \\
\hline 4. Capsules: Cs & $\begin{array}{l}3.5 \\
1.1\end{array}$ & $\begin{array}{l}23,000,000 \\
21,000,000\end{array}$ & $\begin{array}{l}115,000 \\
140,000\end{array}$ & $\begin{array}{l}\text { Capsules of } \mathrm{CsCl} \\
\text { Capsules of } \mathrm{SrF}_{2}\end{array}$ & $\begin{array}{l}\text { Likely if overpack is } \\
\text { unacceptable }\end{array}$ \\
\hline $\begin{array}{l}\text { 5. Transuranic wastes } \\
\text { Remotely handied } \\
\text { Contact handled }\end{array}$ & $\begin{array}{r}2,500+14 / y r \\
70,000+1500 / y r\end{array}$ & $\begin{array}{r}1,000 \\
25-50\end{array}$ & $\begin{array}{r}1-2 \\
0.5-1.5 \\
\end{array}$ & $\begin{array}{l}\text { Wide variety of materials with } \\
\text { TRU > } 100 \mathrm{nCl} / \mathrm{g}\end{array}$ & $\begin{array}{l}\text { Likely for only a small } \\
\text { fraction unless WIPP-WAC } \\
\text { change substantially }\end{array}$ \\
\hline $\begin{array}{l}\text { 6. Low-level radioactive waste } \\
\text { DOE } \\
\text { Commercial: Class A } \\
\text { Commerclal: Class B } \\
\text { Commercial: Class C } \\
\text { Commerclal: > Class C }\end{array}$ & $\begin{array}{l}38,000 / y r \\
24,000 / y r^{b} \\
63+20 / y r\end{array}$ & $\begin{array}{r}9-27 \\
0.6 \\
60 \\
0.1-7,000 \\
>0.1-\text { high }\end{array}$ & $\begin{array}{r}0.01-0.05 \\
0.03-0.1 \\
15 \\
0.003-115 \\
>0.003-\text { high }\end{array}$ & $\begin{array}{l}\text { Extremely wide variety of } \\
\text { materials with }<100 \mathrm{nCl} / \mathrm{g}\end{array}$ & $\begin{array}{l}\text { Lkely for LLW from tank } \\
\text { Wasle processing. Untikely } \\
\text { for most other LLW. }\end{array}$ \\
\hline $\begin{array}{l}\text { 7. Low-level mixed waste } \\
\text { Commerclal } \\
\text { DOE }\end{array}$ & $\begin{array}{r}2,100 \\
138,000\end{array}$ & $\begin{array}{r}\text { Not quantifiable; } \\
\text { low }\end{array}$ & $\begin{array}{r}\text { Not quantiliable; } \\
\text { low }\end{array}$ & $\begin{array}{l}\text { Extremely wide variety of } \\
\text { materials with }<100 \mathrm{nCl} / \mathrm{g} \text { and } \\
\text { hazardous chemicals }\end{array}$ & $\begin{array}{l}\text { Likely in selected } \\
\text { applications, but extent is } \\
\text { unpredictable }\end{array}$ \\
\hline 8. Surplus plutonium & 2 & $11,000,000$ & 44,000 & $\begin{array}{l}\text { Plutonium in a variety of forms, } \\
\text { mostly metal }\end{array}$ & $\begin{array}{l}\text { Either vitrification or } \\
\text { irradiation will be used }\end{array}$ \\
\hline 9. Environmental restoration & $78,000,000$ & $\begin{array}{r}\text { Not quantifiable; } \\
\text { low with small- } \\
\text { volume } \\
\text { exceptions }\end{array}$ & $\begin{array}{r}\text { Not quantifiable } \\
\text { Low with small- } \\
\text { volume } \\
\text { exceptions }\end{array}$ & $\begin{array}{l}\text { Extremely wide variety of } \\
\text { materials and contamination }\end{array}$ & $\begin{array}{l}\text { High-toxicity wastes and } \\
\text { some in-situ are likely. } \\
\text { Unlikely for the bulk of the } \\
\text { waste. }\end{array}$ \\
\hline
\end{tabular}

- Fixed values are existing volumes which are given where production has essentially ceased or where disposal rates are approximately equal to production rates. Rates are given where volumes continue to increase significantly.

- Sum of annual production rates for Classes A, B, and C. 


\section{LIGHT-WATER-REACTOR SPENT FUEL}

GENESIS:

DESCRIPTION:
Uranium dioxide fuel that have been irradiated for 3-5 years in the approximately 100 civilian pressurized-water reactors (PWRs; $2 / 3$ of capacity) and boiling water reactors (BWRs; $1 / 3$ of capacity) to produce electric power.

- Basic component is a fuel rod or fuel element, which is a stack of right-circular cylindrical uranium dioxide fuel pellets in a welded Zircaloy tube. Zircaloy is a metal alloy composed primarily of zirconium with small amounts of tin and iron.

- The rods are held in a square array with a metal lattice grid spacer typical composed of Zircaloy but with some made of nickel alloys.

- The array of rods is held together in the axial direction with tie rods (typically made of Zircaloy) attached to metal end pieces (typically made of stainless steel) to constitute a fuel assembly.

- BWR fuel assemblies are enclosed by a solid sheet of Zircaloy called a fuel channel along the length of the fuel assembly.

\begin{tabular}{|c|c|c|c|c|}
\hline \multicolumn{3}{|c|}{ Attributo } & PWR & BWR \\
\hline Dlameter/width, cm & \multicolumn{2}{|l|}{$\begin{array}{l}\text { Fuel pellet } \\
\text { Fuel rod } \\
\text { Assembly }\end{array}$} & $\begin{array}{l}0.82 \\
0.95 \\
21.4 \\
\end{array}$ & $\begin{array}{l}1.06 \\
1.25 \\
13.9 \\
\end{array}$ \\
\hline Fuel rods per assembly & \multicolumn{2}{|l|}{$\begin{array}{l}\text { Array } \\
\text { Number }\end{array}$} & $\begin{array}{r}17 \times 17 \\
264\end{array}$ & $\begin{array}{r}8 \times 8 \\
63\end{array}$ \\
\hline Height, m & \multicolumn{2}{|l|}{$\begin{array}{l}\text { Fuel stack } \\
\text { Rod } \\
\text { Assembly }\end{array}$} & $\begin{array}{l}3.66 \\
3.85 \\
4.06\end{array}$ & $\begin{array}{l}3.76 \\
4.06 \\
4.47 \\
\end{array}$ \\
\hline \multicolumn{3}{|l|}{ Assembly weight, $\mathrm{kg}$} & 658 & 320 \\
\hline Fuel per assembly, kg & \multicolumn{2}{|l|}{$\begin{array}{l}\text { Uranium metal } \\
\text { Uranium dioxide }\end{array}$} & $\begin{array}{l}461 \\
523\end{array}$ & $\begin{array}{l}183 \\
208\end{array}$ \\
\hline \multicolumn{3}{|c|}{ Metal hardware per assembly, $\mathrm{kg}$} & 135 & 112 \\
\hline \multicolumn{3}{|l|}{ Assembly volume, $\mathrm{m}^{3}$} & 0.186 & 0.086 \\
\hline \multicolumn{3}{|c|}{ Avg. specific power, MWMg U } & 37.5 & 25.9 \\
\hline Bumup, GWdMg $U$ & \multicolumn{2}{|l|}{$\begin{array}{l}\text { Historical } \\
\text { Future }\end{array}$} & $\begin{array}{l}33 \\
60 \\
\end{array}$ & $\begin{array}{r}27.5 \\
46 \\
\end{array}$ \\
\hline \multicolumn{3}{|c|}{ 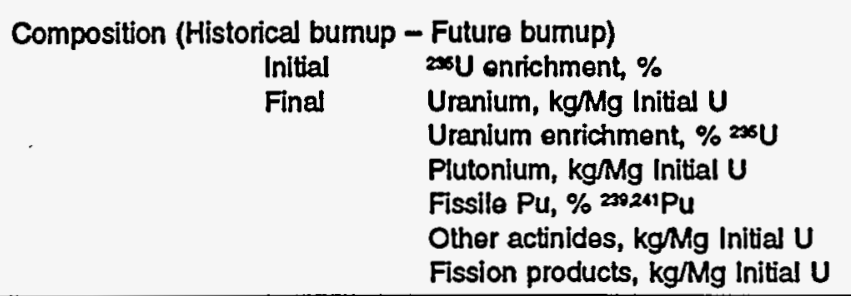 } & $\begin{array}{r}3.30-4.73 \\
955.4-922.2 \\
0.84-0.54 \\
9.47-14.38 \\
71-62 \\
0.71-1.8 \\
34.4-61.6\end{array}$ & $\begin{array}{r}2.77-3.64 \\
962.5-937.1 \\
0.79-0.57 \\
8.26-12.3 \\
72-65 \\
0.59-1.50 \\
28.6-49.1\end{array}$ \\
\hline \multicolumn{2}{|c|}{ Inventory (Annual Addition - Cumulative), Mg Initial U } & $\begin{array}{l}1994 \\
2000 \\
2010 \\
2020\end{array}$ & $\begin{array}{r}1207-19,024 \\
1300-27,400 \\
1400-39,000 \\
700-50,200\end{array}$ & $\begin{array}{l}675-10,788 \\
600-14,900 \\
700-21,400 \\
400-26,900\end{array}$ \\
\hline
\end{tabular}




\section{DOE-RESPONSIBILITY SPENT FUELS}

GENESIS:

DESCRIPTION:

REFERENCES:
Irradiated fuel produced in a diverse array of DOE-owned facilities or for which DOE has assumed responsibility. Principal sources of these spent fuels are as follows:

- Nuclear weapons production complex such as Hanford $\mathrm{N}$-reactor fuel and unreprocessed production reactor fuel at Savannah River Site.

- Naval nuclear reactors.

- A diverse assortment of research, test, and demonstration reactors.

- DOE-responsibility spent nuclear fuels have an extremely wide-ranging assortment of shapes, forms, and characteristics. A categorization system for these fuels has been developed along 7 dimensions:

- Enrichment: High, low, natural, depleted

- Fuel Type: hydride, oxide, alloy, carbide, etc.

- Fuel Matrix: $\mathrm{Zr}$, Al, stainless steel, graphite, etc.

- Cladding: Zircaloy, Al, stainless steel, etc.

- Actinide Content: Minor actinides, Pu

- Other Materials Present: graphite, $\mathrm{Na}, \mathrm{Ca}, \mathrm{B}$, etc.

- Burnup: High, medium, low

More detailed characterization of fuels comprising the majority of the inventory is contained in some of the references.

- Understanding the DOE spent nuclear fuel inventory is further complicated by the fact that these materials are stored at a variety of sites and facilities. It is likely that not all of these materials have yet been identified, although what remains to be included is likely to add little to the existing inventory.

- The largest amount of this material is unreprocessed production reactor fuel stored in basins at Hanford, and contains about $2100 \mathrm{MgU}$.

- A substantial amount of Al-clad fuels are stored at Savannah River Site.

- The Idaho site has a substantial amount of a wide variety of fuel stored ranging from Naval reactor to the core that was destroyed in the Three Mile Island Accident to HTGR fuel from Fort St. Vrain.

- The production of DOE-responsibility spent fuels has largely ceased with the following major exceptions:

- Naval reactor fuels

- Research reactor fuels: U.S. and other countries

- Potential new fuels from resumption of tritium production

DOE 1992, 1993, 1994b, 1995a 


\section{DOE "TANK" WASTES}

GENESIS:

DESCRIPTION:

REFERENCES:
Initially-acid wastes from the reprocessing of spent fuels or processing of irradiated targets to recover valuable constituents by applying a variety of chemical technologies. Most of this is classified as high-level waste, although some is transuranic waste and some low-level waste. Most of the material was neutralized by adding an excess of sodium hydroxide, resulting in the precipitation of many chemicals. Additionally, some of the tank wastes have been further separated and concentrated. There is now about $380,000 \mathrm{~m}^{3}$ of radioactive mixed waste stored in 332 tanks at Savannah River Site, Hanford Site, Idaho Chemical Processing Plant, West Valley Demonstration Project, and Oak Ridge National Laboratory.

Alkaline wastes comprise the largest volume of DOE tank wastes and have roughly similar characteristics. These wastes are composed of one or more of the following constituents:

- Liquid: Supernatant and drainable interstitial liquid in the tanks. Alkaline liquids contain substantial amounts of dissolved chemicals, especially sodium salts such as the hydroxide and nitrate/nitrite, often near or at their respective solubility limit. Acidic liquids typically contain only process chemicals, including much lower sodium concentrations, because they have not been neutralized.

- Salt Cake: A crystalline mixture of chemical salts that were precipitated when neutralized liquids were concentrated to reduce storage volume or potential waste mobility. Composed of the same mix of chemicals that are dissolved in the liquid.

- Sludge: A generally thick, amorphous mixture of relatively insoluble chemicals that precipitated as a result of neutralization. Iron and aluminum compounds are typically important, but sludges are usually heterogeneous and contain a wide variety of cations and anions as well as interstitial salt cake or liquid.

- Slurry: Tank waste comprised of solid particles suspended in a liquid. Most of the solids are alkaline nitrate salts that crystallized when liquid wastes were concentrated, but some solids similar to sludges are also present. Only found in double-shell tanks at Hanford.

- Calcine: A granular, flowable solid (similar to powdered detergent) resulting from heating liquid wastes to the point where all of the water is evaporated but where the more stable oxygen-bearing anions (nitrate, sulfate) are not decomposed to oxides. Only found at ICPP.

- Zeolite: An inorganic ion exchange material that has been used to sorb and precipitate radioactive cesium from liquids at West Valley.

- Precipitate: Radioactive cesium that has been precipitated from liquid waste at the Savannah River Site using potassium tetraphenyl borate. 


\begin{tabular}{||l|r|r|r|r|r|r|r|r||}
\hline & \multicolumn{9}{|c|}{ Waste Location and Type } \\
\hline & \multicolumn{3}{|c|}{ Savannah River Site } & \multicolumn{5}{c||}{ Hanford Site } \\
\hline Characteristic & Liquid & Sludge & Salt Cake & Precipitate & Liquid & Sludge & Salt Cake & Slurry \\
\hline Volume, 103 $\mathrm{m}^{3}$ & 59.3 & 14.3 & 53.1 & 0.2 & 25.1 & 46 & 93 & 94.7 \\
\hline Radioactivity, MCl & 86.4 & 400.9 & 145.0 & 0.1 & 19.9 & 110.3 & 11.5 & 62.1 \\
\hline Water, Wt \% & 71.0 & 55.0 & 6.4 & 88.5 & 40.2 & 33.6 & 10.5 & 56.2 \\
\hline Density & 1.1 & 1.4 & 1.9 & 1.05 & 1.6 & 1.7 & 1.4 & 1.3 \\
\hline
\end{tabular}

\begin{tabular}{||c|c|c|c|c|c|c|c|c||}
\hline \multirow{4}{*}{ Characteristic } & \multicolumn{9}{c|}{ Waste Location and Type } \\
\cline { 2 - 10 } & \multicolumn{3}{|c|}{ West Valley Development Project } & \multicolumn{2}{c|}{$\begin{array}{c}\text { Idaho Chemical } \\
\text { Processing Plant }\end{array}$} & \multicolumn{2}{c|}{$\begin{array}{c}\text { Oak Ridge National } \\
\text { Laboratory }\end{array}$} \\
\cline { 2 - 10 } & $\begin{array}{c}\text { Alkaline } \\
\text { Liquid }\end{array}$ & Sludge & $\begin{array}{c}\text { Acidic } \\
\text { Liquida }\end{array}$ & Zeolite & Liquids & Calcines & Liquild & Sludge \\
\hline Volume, $10^{3} \mathrm{~m}^{3}$ & 1.39 & 0.05 & 0.05 & 0.06 & 7.7 & 3.5 & 0.98 & 0.41 \\
\hline Radioactivity, $\mathrm{Cl}$ & 1.9 & 11.6 & 1.8 & 10.6 & 4.5 & 40.4 & 0.02 & 0.04 \\
\hline Water, $\mathrm{Wt} \%$ & 60.5 & & 40.0 & & $60-77$ & 0 & 68.5 & 52.2 \\
\hline Density, g/cm & & & & & $1.1-1.3$ & $1.1-1.8$ & 1.23 & 1.35 \\
\hline
\end{tabular}

-This waste was recently combined with the neutralized waste at WVDP. 


\section{CAPSULES OF SEPARATED RADIOCESIUM AND RADIOSTRONTIUM}

GENESIS:

During the late 1960 s and 1970 s the contents of many Hanford tanks were recovered and chemically processed to remove radiocesium and radiostrontium, after which the wastes were returned to the tanks. This was done to reduce the heat and radioactivity generated by the wastes in the tank, thus allowing its volume to be further reduced. The radiocesium and radiostrontium in the separate streams wère processed into solids and encapsulated.

DESCRIPTION:

\begin{tabular}{|c|c|c|}
\hline \multicolumn{3}{|c|}{ Description of Hanford Radioisotope Capsules } \\
\hline Characteristic & Radiocesium Capsules & $\begin{array}{l}\text { Radiostrontium } \\
\text { Capsules }\end{array}$ \\
\hline Number of Capsulesa & 1328 & 605 \\
\hline Capsule Construction & $\begin{array}{l}\text { Double-encapsulated } \\
\text { cylinders } \\
\text { (SS } 316 \text { LSS 316L) with } \\
\text { welded lids }\end{array}$ & $\begin{array}{l}\text { Double-encapsulated } \\
\text { cylinders } \\
\text { (Hastelloy C-276/SS } \\
\text { 316L) with welded lids }\end{array}$ \\
\hline $\begin{array}{c}\text { Capsule Dimensions } \\
\text { Length, } \mathrm{cm} \\
\text { Diameter, cm }\end{array}$ & $\begin{array}{l}53 \\
6.67 \\
\end{array}$ & $\begin{array}{l}51 \\
6.67\end{array}$ \\
\hline Capsule contents & $\begin{array}{l}\text { Melt-cast CsCl } \\
38,500 \mathrm{Ci} \text { (average) } \\
260 \mathrm{~W} \text { (average) }^{\mathrm{b}}\end{array}$ & $\begin{array}{l}\text { Compacted } \mathrm{SrF}_{2} \\
\text { powder } \\
40,100 \mathrm{Ci} \text { (average) } \\
193 \mathrm{~W} \text { (average) }^{\mathrm{b}}\end{array}$ \\
\hline $\begin{array}{l}\text { Inventory } \\
\text { Volume, } \mathrm{m}^{3} \\
\text { Radioactivity, MCi }\end{array}$ & $\begin{array}{c}2.4 \\
55.5^{\circ}\end{array}$ & $\begin{array}{r}1.1 \\
23.0\end{array}$ \\
\hline
\end{tabular}

an additional 249 radiocesium capsules and 35 radiostrontium capsules have been dismantled. The contents are not expected to be returned to Hanford. bAs of January 1, 1995.

Includes $-200 \mathrm{Ci}$ of ${ }^{135} \mathrm{Cs}$ which has a half-life of 3 million years.

REFERENCES: $\quad$ DOE 1991, 1995a, 1996b; ERDA 1977 


\section{TRANSURANIC WASTES}

GENESIS:

DESCRIPTION:

REFERENCES:
- Transuranic (TRU) wastes are materials (a) contaminated with alpha-emitting radionuclides that have an atomic number greater than 92 and half-lives greater than 20 years such that the total concentration of these radionuclides exceeds $100 \mathrm{nCi} / \mathrm{g}$ of waste at the time of assay. Before $1984 \mathrm{TRU}$ wastes were defined as those containing $10 \mathrm{nCi} / \mathrm{g}$ of such radionuclides, and some TRU waste in storage has TRU radionuclide concentrations in the $10-100 \mathrm{nCi} / \mathrm{g}$ range.

- Wastes contaminated with other alpha-emitting radionuclides $\left(e . g ., 233 \mathrm{U},{ }^{244} \mathrm{Cm}\right)$ or radionuclides that eventually decay to other alpha-emitting radionuclides (e.g., ${ }^{24} \mathrm{Pu}$ ) may be managed as if they were TRU waste according to DOE orders this is not codified in law.

- TRU wastes are produced as secondary wastes during the processing (e.g., separation, fabrication) of materials (e.g., spent fuel, targets, recovered plutonium). Such wastes are produced only by the Department of Energy. Similar wastes produced by commercial operations are considered to be Greater-Than-Class-C low-level waste.

- TRU wastes exist as a wide range of materials that have been contaminated with sufficient amounts of TRU radionuclides as described above:

- Assorted solid trash such as protective clothing, paper, rags, glass, tools, and equipment that have been stored awaiting further processing and/or disposal.

- Liquids, sludges, and a variety of chemical compounds that are being stored awaiting further processing and disposal

- Waste ( $>10 \mathrm{nCi} / \mathrm{g}$ ) that was managed by burial in near-surface trenches before 1970

- Soil contaminated by leaking TRU waste containers or the use of soil columns as an ion exchange medium to retard radionuclides released in dilute liquid waste streams

- TRU wastes are further subclassified as "contact handled" or "remote handled", depending on whether the dose rate at the surface of the waste package is less or greater than $200 \mathrm{mrem} / \mathrm{hr}$. Remotely-handled TRU (RH-TRU) wastes constitute about $3 \%$ of the total volume and $25 \%(0.2 \%)$ of the total (TRU) radioactivity. The higher radiation levels of RH-TRU wastes results from the presence of fission products, primarily ${ }^{137} \mathrm{Cs}$.

- TRU wastes are also further subclassified as to whether they are "mixed" wastes by virtue of containing chemically hazardous constituents regulated under the Resource Conservation and Recovery Act (primarily), but also the Toxic Substances Control Act or various state regulations. About $55 \%$ of TRU wastes are mixed wastes.

DOE 1991, 1994a, 1995a 


\section{LOW-LEVEL RADIOACTIVE WASTES}

GENESIS:

DESCRIPTION:
- Low-level waste (LLW) is defined by exclusion: it is waste that is not spent fuel, high-level waste, transuranic waste, or byproduct material such as uranium and thorium mill tailings. As such, it must contain less than $100 \mathrm{nCi} / \mathrm{g}$ of TRU radionuclides and limits also exist on medium-to-long-lived fission and activation products as well as non-TRU actinides. LLW containing hazardous chemicals is considered separately in Sect. 7.

- Commercial LLW is governed by NRC regulations. It is managed in three classes $(A, B, C)$ with increasing radionuclide concentrations and increasingly stringent disposal requirements. Commercial LLW having radionuclide concentrations greater than Class $\mathrm{C}$ is also produced. These wastes are produced by utilities generating electricity using nuclear power plants, commercial firms using radioactive materials to manufacture various items and substances, hospitals that use radionuclides for diagnosis and treatment, and research institutions that use radionuclides in R\&D.

- DOE LLW is governed by DOE orders. Sub-classes of DOE LLW are defined on a site-by-site basis, as are waste acceptance criteria which may vary widely. These wastes result from a wide range of DOE activities related to production of nuclear weapons and R\&D.

- Commercial LLW is composed of a collage of waste types as diverse as their sources:

- Irradiated components, contaminated materials, and immobilized liquids and sludges from nuclear power plant operations

- Contaminated trash from nuclear fuel cycle operations (e.g., fuel fabrication)

- Industrial activities (e.g., radiopharmaceuticals, manufacture of sealed sources)

- Medical wastes from radiopharmaceuticals administered to humans and radioactive sources used to treat diseases

- Research activities, primarily tracers used in biological research but also in geological research

- In part, DOE LLW is composed of many of the same waste types as commercial LLW because it undertakes many similar activities. In addition, a large amount of DOE LLW has been produced by the processing of materials related to the production of nuclear weapons which has no parallels in the commercial sector. This not only includes general process wastes, but unusual waste forms such as grouted LLW resulting from the processing of high-level waste at Savannah River Site and grouted waste that was injected into the earth at Oak Ridge National Laboratory.

- The preponderance of commercial and DOE LLW is emplaced in near-surface disposal facilities relatively soon after it is generated. Thus, the amount of LLW in storage is small compared to what is already emplaced.

- One exception to this is LLW that has radionuclide concentrations greater than Class C. By law, disposal of this waste is the responsibility of the Federal government (i.e., DOE). Its disposal destination and attendant waste acceptance criteria are yet to be determined.

REFERENCES: $\quad$ DOE 1995a; LOGHRY 1995 


\section{LOW-LEVEL MIXED WASTES}

GENESIS:

DESCRIPTION:
- Mixed low-level waste (MLLW) contains both radionuclides and hazardous chemicals

- Low level radioactive waste is defined in Sect. 6

- Hazardous chemicals are those defined in the Resource Conservation and Recovery Act (RCRA), although chemicals defined by other acts (e.g., Toxic Substances Control Act, state regulations) are included in this category

- Although not specifically denominated as such, many wastes in earlier sections are actually mixed wastes. In particular, tank wastes and many transuranic wastes contain hazardous chemicals that result in their being considered to be mixed

- Commercial MLLW is composed of a variety of materials from diverse operations and institutional sources.

- Annual production in 1990 was about $3500 \mathrm{~m}^{3}$, of which the largest portion was liquid scintillation fluids.

- Other materials comprising commercial MLLW include waste oils, chlorinated organic chemicals, chlorofluorocarbons, contaminated heavy metals (e.g., lead, mercury), and corrosive aqueous liquids.

- A large portion of commercial MLLW (especially the organic chemicals) are treated soon after being generated.

- A total of about $2,100 \mathrm{~m}^{3}$ of commercial MLLW was in storage in 1990. Contaminated heavy metals constituted the largest volume with contaminated organic chemicals closely following. It is estimated that about $75 \%$ of this is waste being accumulated prior to treatment.

- The most important generators (in decreasing order of importance) are industrial, academic, government, medical, and civilian nuclear power.

- Details are included in tables that follow.

- DOE MLLW is composed of an extremely wide variety of materials from diverse operations and legacies

- The inventory of DOE MLLW is about $140,000 \mathrm{~m}^{3}$ of which $68 \%$ is contaminated inorganic solids and contaminated soils and gravels. Mostly-inorganic contaminated debris accounts for most of the remainder.

- Projected generation of DOE MLLW for the next 5 years is estimated to be about $31,000 \mathrm{~m}^{3}$ (ignoring final waste forms) which is composed of mostly contaminated inorganic solids atthough liquids are more significant than in the legacy material.

- The vast majority of these wastes are being stored at DOE sites and the rate of treatment and disposal is far less than the generation rate

REFERENCES: $\quad$ DOE 1995a,b; KLEIN 1992 


\section{SURPLUS PLUTONIUM}

GENESIS:

High-quality plutonium was produced and separated for military purposes for decades. Recent agreements to substantially reduce the size of nuclear arsenals will lead to some of the existing plutonium stockpile no longer being needed for national security purposes.

In the U.S. the primary permanent disposition alternatives being considered are to:

(a) Convert the Pu to the oxide, fabricate it into spent fuel, irradiate it in lightwater reactors, and then dispose of it in a repository as spent fuel, or

(b) Incorporate the Pu directly into a waste form for subsequent disposal in a repository.

The other country with significant amounts of surplus military Pu is Russia. The Russians view the Pu as a valuable fuel resource and plan on using it as such. If the Russians were to sell the Pu to the U.S., its permanent disposition would presumably be the same as stated above. It should be noted that the Russians do not sharply distinguish military and civilian plutonium stocks as in the U.S., and most $\mathrm{Pu}$ has been and continues to be generated in power reactors.

DESCRIPTION: The composition of military Pu has been stated to be approximately as follows:

$$
\begin{array}{lr}
{ }^{239} \mathrm{Pu} & 93.0 \% \\
{ }^{240} \mathrm{Pu} & 6.0 \% \\
{ }^{241} \mathrm{Pu} & 0.5 \%
\end{array}
$$

The amounts of Pu that will be declared surplus to national security needs are officially stated as follows:

$$
\begin{array}{lc}
\text { United States } & 38 \mathrm{Mg} \\
\text { Russia } & 100 \mathrm{Mg}
\end{array}
$$

The Russians continue to produce military-grade $\mathrm{Pu}$ at a rate of about $1.5 \mathrm{Mg} / \mathrm{y}$ because of the need for electric power from three production reactors that remain in operation.

About $28 \mathrm{Mg}$ of the U.S. surplus plutonium exists as the metal and the rest in a variety of forms (oxide, unirradiated fuel, irradiated fuel, and other forms).

REFERENCES: $\quad$ DIAKOV 1995; DOE 1996a; ALBRIGHT 1993 


\section{DOE ENVIRONMENTAL RESTORATION WASTES}

GENESIS:

The has hundreds of unused legacy sites and facilities that are contaminated with radionuclides, hazardous chemicals, or combinations thereof. It has undertaken a long-term environmental restoration program to remediate the sites, and to decontaminate and decommission (D\&D) the facilities.

DESCRIPTION:

- Environmental restoration wastes are not well characterized because:

- In-situ legacy contents are often not well characterized concerning the nature of the materials and spread of contamination

- The processes by which D\&D of facilities will be accomplished is not yet known. Thus, the secondary waste streams have not yet been defined.

- Taken as a whole, environmental restoration wastes are projected to be less heavily contaminated and more heterogenous than other waste types.

The wastes are segregated into two broad categories: contaminated soil (including sediment and sludge) and contaminated debris (metal, concrete, wood, asphalt, brick, plastic, rubble).

- A small fraction of this waste $\left(-170,000 \mathrm{~m}^{3}\right)$ is residues from processing of highly concentrated uranium ores during WW II, and as a consequence contains very high concentrations of radium.

REFERENCES: $\quad$ DOE 1995a; NAS 1995 
ALBRIGHT $1993 \quad$ D. Albright, F. Berkhout, and W. Walker, World Inventory of Plutonium and HighlyEnriched Uranium, 1992, Oxford University Press (1993).

CROFF 1980a

A. G. Croff, ORIGEN2 - A Revised and Updated Version of the Oak Ridge Isotope Generation and Depletion Code, ORNL-5621 (July 1980).

CROFF 1980b

A. G. Croff and C. W. Alexander, Decay Characteristics of Once-Through LWR and LMFBR Spent Fuels, High-Level Wastes, and Fuel Assembly Structural Material Wastes, ORNLTM-7431 (November 1980).

CROFF 1982

A. G. Cróff, M. S. Liverman, and G. W. Morrison, Graphical and Tabular Summaries of Decay Characteristics for Once-Through PWR, LMFBR, and FFTF Fuel Cycle Materials, ORNLTM-8061 (January 1982).

DIAKOV 1995

A. S. Diakov, Disposition of Separated Plutonium: An Overview of the Russian Program, paper presented at the Fifth International Conference on Radioactive Management and Environmental Remediation, Berlin, Germany (September 3-8, 1995.

DOE 1991

Integrated Data Base for 1991: U.S. Spent Fuel and Radioactive Waste Inventories, Projections, and Characteristics, DOE/RW-0006, Rev. 7 (October 1991).

DOE 1992

Characteristics of Potential Repository Wastes, DOE/RW-0184-R1 (July 1992).

DOE 1993

Spent Fuel Working Group Report on Inventory and Storage of The Department's Spent Nuclear Fuel and Other Irradiated Nuclear Materials and Their Environmental, Safety, and Health Vulnerabilities (November 1993).

DOE 1994a

Integrated Data Base Report for 1993: U.S. Spent Fuel and Radioactive Waste Inventories, Projections, and Characteristics, DOE/RW-0006, Rev. 9 (March 1994).

DOE 1994b

DOE-Owned Spent Nuclear Fuel Strategic Plan (December 1994).

DOE 1995a

Integrated Data Base Report $\lambda$ 1994: U.S. Spent Nuclear Fuel and Radioactive Waste Inventories, Projections, and Characteristics, DOE/RW-0006, Rev. 11 (September 1995).

DOE 1995b

1995 Mixed Waste Inventory Summary Report, U.S. DOE Office of Environmental Management (December 1995)

DOE $1996 a$

Department of Energy Declassifies Location and Forms of Weapon-Grade Plutonium and Highly-Enriched Uranium Inventory Excess to National Security Needs, DOE FACTS, press release (1996).

DOE 1996b

Draft Environmental Impact Statement for the Tank Waste Remediation System, DOE/EIS-0189D (April 1996).

ERDA 1977

Alternatives for Long-Term Management of Defense High-Level Radioactive Waste - Hanford Reservation, ERDA 77-44 (September 1977). 
GEPHART 1995

INEL 1993

KLEIN 1992

R. E. Gephart and R. E. Lundgren, Hanford Tank Clean Up: A Guide to Understanding the Technical Issues, PNL-10773 (1995).

Spent Fuel Background Report Predecisional Draft, SNF-5800-450-004 (December 1993).

J. A. Klein et al., National Profile on Commercially Generated Low-Level Radioactive Mixed Waste, NUREG/CR-5938 (December 1992).

KUPFER 1993

M. J. Kupfer, Disposal of Hanford Site Tank Waste, WHC-SA-1576-FP (September 1993).

LEE 1991

D. D. Lee and D. O. Campbell, Treatment Requirements for Decontamination of ORNL Low-Level Liquid Waste, ORNLTM-11799 (October 1991).

LOGHRY 1995

S. L. Loghry et al., Low-Level Radioactive Waste Source Terms for the 1992 Integrated Data Base, ORNLTM-11710 (January 1995).

LUDWIG 1989

S. B. Ludwig and J. P. Renier, Standard-and Extended-Burnup PWR and BWR Reactor Models for the ORIGEN2 Computer Code, ORNLTM-11018 (December 1989).

NAS 1995

National Academy of Sciences, Safety of the High-Level Uranium Ore Residues at the NFSS, Lewiston, New York (1995).

RODDY 1986

J. W. Roddy et al., Physical and Decay Characteristics of Commercial LWR Spent Fuel, ORNLTM-9591/R1.

SEARS 1990

M. B. Sears et al., Sampling and Analysis of Radioactive Liquid Wastes and Sludges in the Melton Valley and Evaporator Facility Storage Tanks at ORNL, ORNLTM-11652 (September 1990). 


\section{DISCLAIMER}

This report was prepared as an account of work sponsored by an agency of the United States Government. Neither the United States Government nor any agency thereof, nor any of their employees, makes any warranty, express or implied, or assumes any legal liability or responsibility for the accuracy, completeness, or usefulness of any information, apparatus, product, or process disclosed, or represents that its use would not infringe privately owned rights. Reference herein to any specific commercial product, process, or service by trade name, trademark, manufacturer, or otherwise does not necessarily constitute or imply its endorsement, recommendation, or favoring by the United States Government or any agency thereof. The views and opinions of authors expressed herein do not necessarily state or reflect those of the United States Government or any agency thereof. 